\title{
Pierwsze miesiące działalności sądów pokoju w Apelacji Poznańskiej w 1920 roku w świetle akt Sądu Apelacyjnego w Poznaniu
}

Działalność sądów pokoju przy sądach powiatowych w byłej dzielnicy pruskiej jest jednym z ciekawych, a jednocześnie mniej poznanych aspektów przejmowania wymiaru sprawiedliwości przez władze polskie II RP1 . Prace Komisariatu Naczelnej Rady Ludowej, a następnie Departamentu Sprawiedliwości Ministerstwa byłej Dzielnicy Pruskiej (dalej: MbDP) w ciągu roku 1919 zostały już szeroko omówione w literaturze przedmio$t^{2}$. Jednym $z$ elementów tych działań było uzupełnienie ogromnych braków osobowych wśród polskich prawników (w szczególności sędziów) i innych pracowników wymiaru sprawiedliwości na obszarze dawnego zaboru pruskiego. W celu tym sięgnięto choćby po kadry z Galicji. Inny sposób radzenia sobie z niedoborami stanowiło powierzenie orzecznictwa w drobnych sprawach sędziom niezawodowym, wywodzącym się z godnych zaufania przedstawicieli polskiego społeczeństwa - ziemian, przedsiębiorców czy nauczycieli.

Celem niniejszego artykułu jest przybliżenie wybranych aspektów działania sądów pokoju w pierwszym półroczu 1920 roku - a zatem bezpośrednio po ich utworzeniu. Temat ten wciąż pozostaje zbadany głównie na poziomie analizy aktów prawnych, przy braku oceny faktycznej aktywności sądów. Zakres artykułu ograniczony został do takich spośród nich, które podlegały Sądowi Apelacyjnemu w Poznaniu. Pominięto zatem te podległe Sądowi Apelacyjnemu w Toruniu. Podstawę źródłową opracowania stanowiły

1 Vid. M. Materniak-Pawłowska, Ustrój sqqdownictwa powszechnego II Rzeczypospolitej, Poznań 2003, s. 122-141 (szczególnie s. 127-129). Prowadzone są również badania nad funkcjonowaniem poszczególnych sądów pokoju - vid. Sz. Paciorkowski, Sąd Pokoju w Pleszewie (19201926), [w:] „Rocznik Pleszewski”, 2011, s. 193-210.

2 Vid. Zbiór rozporzqdzeń i okólników Ministerstwa b. Dzielnicy Pruskiej z r. 1920 majacych zasadnicze znaczenie dla wymiaru sprawiedliwości. Z upoważnienia Ministerstwa byłej Dzielnicy Pruskiej zestawili: dr T. Stark i dr J. Zagórowski z przedmową T. Zajączkowskiego, Poznań 1921, s. 1-23; A. Gulczyński, Ministerstwo bytej Dzielnicy Pruskiej (1919-1922), Poznań 1995, s. 84-85, 107-137; M. Materniak-Pawłowska, Ustrój sq̨downictwa..., s. 38-46. 
w głównej mierze akta Sądu Apelacyjnego w Poznaniu, zachowane w poznańskim Archiwum Państwowym ${ }^{3}$.

Ograniczona objętość artykułu powoduje konieczność skupienia się na wybranych elementach działalności sądów pokoju. Celem niniejszego szkicu jest przedstawienie ram prawnych działalności sądów w pierwszym okresie ich działania i procesu ich powstawania, a także ukazanie niektórych kwestii istotnych dla praktycznej działalności sędziów pokoju - problemów kadrowych, wysokości wynagrodzenia i kontroli jakości orzecznictwa. Artykuł ma w założeniu przedstawić możliwe problemy badawcze nasuwające się przy badaniu sądów pokoju w byłej dzielnicy pruskiej, stanowiąc wstęp do szerszych badań.

\section{Ramy prawne i początek działalności sądów pokoju}

W siedemdziesiątym numerze Tygodnika Urzędowego, organu publikacyjnego nowych władz, noszącym datę 24 grudnia 1919 roku ukazało się Rozporządzenie Ministra byłej Dzielnicy Pruskiej z dnia 15 grudnia 1919 roku o przejściu wymiaru sprawiedliwości w bytej dzielnicy pruskiej na Rzeczpospolita Polskq (nr 180), co na obszarze objętym tak zwaną linią demarkacyjną nastąpić miało z dniem 1 stycznia 1920 roku ${ }^{4}$ Rozporządzeniu temu towarzyszył pakiet dziewięciu rozporządzeń dotyczących działania wymiaru sprawiedliwości po przejściu w ręce polskie wydanych 15 grudnia 1919 r. (nr. 181-189). W rozporządzeniu nr 181 odnoszącym się do urzędów i urzędników sądowych w byłej dzielnicy pruskiej określono nazwy nowych sądów: powiatowych (dawne Amtsgericht), okręgowych (Landgericht) oraz apelacyjnych (Oberlandesgericht) $)^{5}$. Zgodnie z załączonym do rozporządzenia nr 182 wykazem sądów do Sądu Apelacyjnego w Poznaniu należały sądy okręgowe: w Poznaniu (obejmujący 16 sądów powiatowych), w Lesznie (8 sądów powiatowych), Ostrowie (8 sądów powiatowych), Gnieźnie (6 sądów powiatowych) i Bydgoszczy (12 sądów powiatowych) ${ }^{6}$.

Kluczowe dla niniejszego artykułu rozporządzenie o urzq̨dzeniu sq̨ów pokoju w bytej dzielnicy pruskiej (nr 186) ${ }^{7}$ wydane zostało przez Ministra byłej dzielnicy pruskiej w porozumieniu z Ministrem Sprawiedliwości na podstawie art. 6 ustawy o tymczasowej organizacji zarządu byłej dzielnicy pruskiej. Rozporządzenie składało się z 11 artykułów. Zgodnie z art. 1 rozporządzenia nr 186 Departament Sprawiedliwości mógł ustanowić

3 Archiwum Państwowe w Poznaniu, Zespół akt Sądu Apelacyjnego w Poznaniu - dalej: APP, SAP.

4 Tygodnik Urzędowy (dalej: Tyg. Urz.), Nr 70, 24.12.1919 r., s. 409; dalej: rozporządzenie nr 180.

5 Rozporządzenie $\mathrm{Nr} 181$ z 15.12 .1919 r. o urzędach i urzędnikach sqqdowych w bytej dzielnicy pruskiej, Tyg. Urz., Nr 70, 24.12 .1919 r., s. 409

6 Rozporządzenie Nr 182 z 15.12.1919 r. o organizacji sądów w byłej dzielnicy pruskiej, Tyg. Urz., $\mathrm{Nr}$ 70, 24.12.1919 r., s. 410.

7 Tyg. Urz., Nr 70, 24.12.1919 r., s. 416; dalej: rozporządzenie nr 186. 
w razie potrzeby sądy pokoju w miejsce lub obok sądów ławniczych lub też w miejsce albo obok sędziów powiatowych w zakresie ich orzecznictwa karnego. Narzędziem wykorzystanym w tym przypadku była przewidziana w obowiązującej w zaborze pruskim niemieckiej ustawie o ustroju sądownictwa z 1877 roku$^{8}$ instytucja sądów ławniczych w sądach powiatowych, sprawujących wymiar sprawiedliwości w sprawach karnych. Niemieckim sądom ławniczym przewodniczył sędzia zawodowy, natomiast zgodnie z przyświecającą twórcom rozporządzenia z 15 grudnia 1919 roku ideą odciążenia polskich sędziów w sądach pokoju od przewodniczącego nie wymagano kwalifikacji na urząd sędziowski (art. 2 rozporządzenia).

Postanowienia art. 1 rozporządzenia nr 186 doczekały się szybkiej realizacji, gdy rozporządzeniem z dnia 23 grudnia 1919 roku - opublikowanym w Tygodniku Urzędowym 30 grudnia 1919 roku - zarządzono ustanowienie sądów pokoju w byłej dzielnicy pruskiej zamiast sądów ławniczych w obwodach 35 sądów powiatowych położonych po polskiej stronie linii demarkacyjnej ${ }^{9}$. Rozporządzenie to weszło w życie 10 stycznia 1920 roku. Pozostawała jeszcze kwestia miejscowości przyznanych Polsce, które znajdowały się poza obrębem linii demarkacyjnej. 24 stycznia 1920 roku w Dzienniku Urzędowym Ministerstwa byłej Dzielnicy Pruskiej opublikowany został Dekret Ministra o przejęciu ziem przyznanych Polsce Traktatem Wersalskim ${ }^{10}$. Natomiast na mocy rozporządzenia z dnia 31 stycznia 1920 roku na Rzeczpospolitą Polską przeszedł wymiar sprawiedliwości na tych terenach, przy czym jego wykonywanie miało się rozpocząć w obwodzie Sądu Apelacyjnego w Poznaniu z dniem 15 lutego 1920 roku. Z tym też dniem w życie wejść miały rozporządzenia $z$ dnia 15 grudnia $1919^{11}$. Wreszcie rozporządzeniem z dnia 12 lutego 1920 roku - analogicznie do rozporządzenia z 23 grudnia 1919 roku - zostały ustanowione sądy pokoju przy sądach powiatowych położonych poza linią demarkacyjną, przy czym rozporządzenie to miało wejść w życie 1 marca 1920 roku $^{12}$.

8 Ustawa o ustroju sądów powszechnych z 27 stycznia 1877 r. (Gerichtsverfassungsgesetz), Reichsgesetzblatt z 1877 r., nr 4, s. 41-76. Polskie brzmienie przepisów wraz ze zmianami - $c f$. J. Kazłużniacki, R. A. Leżański, Postępowanie karne obowiqzujace na Ziemiach Zachodnich Rzeczypospolitej Polskiej, wyd. III, Warszawa - Poznań 1926, s. 1-59 (w szczególności s. 11-22).

9 Rozporządzenie z 23.12.1919 r. o ustanowieniu sq̨ów pokoju w bytej dzielnicy pruskiej, Tyg. Urz. $\mathrm{Nr}$ 71,30.12.1919 r., s. 432. Co ciekawe, sądu pokoju nie ustanowiono w Gostyniu (położonym wszak w obrębie linii demarkacyjnej), uczyniono to dopiero w rozporządzeniu z 12. $02.1920 \mathrm{r}$. Sąd pokoju w Śmiglu ustanowiony został natomiast dwukrotnie - zarówno w rozporządzeniu z 23. 12. 1919 r., jak i z 12. 02. 1920 r. Pierwsi sędziowie dla sądu pokoju w Gostyniu i Śmiglu mianowani zostali przez Ministra już 31.12.1919 r.

10 Dziennik Urzędowy Ministerstwa byłej Dzielnicy Pruskiej, Nr 3 z 1920 r., s. 45 (dalej $\mathrm{DzUMbDP})$.

11 Rozporządzenie z 31 stycznia 1920 r. o przejściu wymiaru sprawiedliwości w obszarze b. dzielnicy pruskiej poza b. linią demarkacyjną na Rzeczpospolitą Polską (DzUMbDP, Nr 6 z 1920 r., s. 109).

12 DzUMbDP, Nr 9 z 1920 r., poz. 76, s. 178. Cf. uwagi w przypisie nr 9 - w rozporządzeniu podano 16 sądów powiatowych, przy których utworzyć miano sądy pokoju, faktycznie dotyczyło 


\section{Pierwszy miesiąc działalności sądów pokoju}

Zgodnie $\mathrm{z}$ art. 8. rozporządzenia $\mathrm{nr} 186$ sędziowie pokoju mieli być nominowani na okres trzyletni, z możliwością wcześniejszego odwołania z ważnych powodów. Pierwsza częściowa listę nazwisk sędziów pokoju przesłana została do Prezesa Sądu Apelacyjnego w Poznaniu i Prezesów sądów okręgowych z Departamentu Sprawiedliwości MbDP w dniu 8 stycznia 1920 roku $^{13}$. Jako datę nominacji sędziów pokoju wskazano 31 grudnia 1919 roku. Dla każdego sądu podano ustaloną liczbę sędziów i ich zastępców, jednakże liczba faktycznie mianowanych sędziów często nie pokrywała się z założeniami. Dla poszczególnych sądów przewidziano od minimalnej liczby 1 sędziego i 1 zastępcy do 8 sędziów i 4 zastępców w Poznaniu ${ }^{14}$. Zachowane w aktach dekrety nominacyjne, podpisane przez Szefa Departamentu Sprawiedliwości dr. Witolda Prądzyńskiego, miały następującą treść: „Minister b. dzielnicy pruskiej zamianował Pana (...) sędzią pokoju w sądzie powiatowym w (...) na okres trzechletni. Wzywa się Pana, abyś urząd ten niezwłocznie objął i abyś się w tym celu u naczelnika sądu powiatowego w (...) zgłosi1"'15. Sędziowie pokoju, którzy otrzymali nominacje, zostali zobowiązani do złożenia przysięgi sędziowskiej na podstawie art. 10 rozporządzenia nr 186, przez co pod względem służbowym i dyscyplinarnym zrównani zostali z sędziami powiatowymi ${ }^{16}$. Zaprzysiężenie sędziów na podstawie nominacji należało do Prezesów sądów okręgowych ${ }^{17}$. Listę 123 mianowanych w styczniu 1920 roku przez Ministra byłej Dzielnicy Pruskiej sędziów

to 14 sądów powiatowych, bez sądów w Gostyniu i Śmiglu, gdzie sady pokoju utworzono już wcześniej.

13 APP, SAP, sygn. 51, s. 4-9 - pismo Departamentu Sprawiedliwości z 8. 01.1920 r. (L. Dz. 1706/20).

14 Zgodnie $z$ art. 7 rozporządzenia nr 186: „W sądach powiatowych o jednym lub dwóch sędziach mianuje się w zasadzie jednego sędziego pokoju i jednego zastępcę. W sądach powiatowych o trzech lub większej liczbie sędziów mianuje się dwóch lub w razie potrzeby więcej sędziów pokoju oraz potrzebną liczbę zastępców”.

15 Dekrety nominacyjne były zwracane po zakończeniu trzyletniej służby sędziego - część trafiła do akt SA w Poznaniu, v. np. APP, SAP, sygn. 364 (Jarocin, 31. 12. 1919 r.); sygn. 428 (Pniewy, 31.12. 1919 r.); sygn. 443, k. 33 (Rogoźno, 31.12.1919 r.); sygn. 452, k. 29 (Środa, 31.12. 1919 r.); sygn. 470, k. 18 (Wolsztyn, 31. 12.1919 r.); sygn. 478, k. 29 (Zbąszyń, 23. 02.1920 r.); sygn. 500, k. 33 (Koronowo; 18. 02.1920 r.).

$16 \mathrm{~W}$ części akt zachowały się protokoły złożenia przysięgi sędziowskiej, zob. np. APP, SAP, sygn. 350, k. 13 (Gniezno, 23. 10. 1920 r.); sygn. 370, k. 10 (Kępno); sygn. 375, k. 18 (Kościan, 26. 10. 1920 r.).

17 APP, SAP, sygn. 491, k. 9 - pismo Departamentu Sprawiedliwości z 3. 04.1920 r. 
pokoju opublikowano 30 stycznia $^{18}$. W ciągu następnych miesięcy Departament Sprawiedliwości przekazywał kolejne dekrety nominacyjne ${ }^{19}$.

Wiele istotnych informacji zawartych zostało w datowanym na 9 stycznia 1920 roku okólniku Departamentu Sprawiedliwości MbDP, zawierającym wskazówki do wykonania rozporządzenia o wprowadzeniu sądów pokoju ${ }^{20}$. We wstępie okólnika podkreślono, iż wystarczająca liczba sędziów pokoju została już mianowana dla wszystkich sądów powiatowych i że będą mogli oni rozpocząć działalność. Część dokumentu poświęcono problemowi ewentualnego mianowania zastępców sędziów:

Dla każdego sądu powiatowego zamianowano taką ilość sędziów pokoju, by pewna ilość ich mogła pełnić funkcje zastępców w razie niemożności wykonywania swych funkcji przez drugiego sędziego. Każdy ze sędziów otrzymał nominację na sędziego pokoju bez wzmianki, czy ma być zajętym stale, czy też jako zastępca. Żadnemu tė̇ z nich nie udzielono w tej mierze wiążących wskazówek. Uczyniono to dlatego, że zgromadzeni w Poznaniu na kursie kandydaci na sędziów objawiali w tej mierze rozmaite życzenia. Niektórzy z nich oświadczyli, że w razie, gdy będą mieli pełnić urząd swój zastępczo, urząd swój złożą. Niektórzy zaś uczynili przyjęcie urzędu sędziego zawisłem od tego, że będą pełnili swój urząd zastępczo. Inni wreszcie już tu w Poznaniu umówili się, że będą swój urząd pełnili kolejno co pewien czas, a więc jeden np. przez dwa tygodnie, a drugi przez dalsze dwa tygodnie i.t. p.

W okólniku zawarto również dalsze zalecenia. Wskazano na konieczność wyznaczenia dni posiedzeń sądów pokoju na cały rok i prowadzenia ewidencji posiedzeń w celu ich kontroli po każdym półroczu. Uznano także za pożądane zorganizowanie przez Prezesów sądów okręgowych konferencji dla nowych sędziów pokoju. Sędziom pokoju polecono sporządzenie wykazu stanu swojej służby, poinformowano o złożeniu zamówienia na noszone przez nich w czasie orzekania szarfy. Zapowiedziano również powołanie przez Departament Sprawiedliwości stałego instruktora dla sędziów pokoju, którego zadaniem byłyby regularne wizytacje sądów i udzielanie sędziom wskazówek. Jednocześnie zwrócono się z apelem do dyrektorów izb odwoławczych przy sądach okręgowych i samych prezesów sądów o bieżącą kontrolę formalnej jakości orzeczeń sędziów pokoju, zwracając przy tym uwagę, iz „ kwestionowanie merytorycznego załatwienia sprawy nie jest dopuszczalne”. Departament Sprawiedliwości wystąpił także do Prezesa poznań-

18 DzUMbDP, nr 4 z 1920 r., s. 79-81.

19 Vid. np. APP, SAP, sygn. 51, s. 14 - pismo Departamentu Sprawiedliwości z 12. 02.1920 r.; s. 16 - pismo z nominacjami z 22. 02.1920 r.; s. 19 - pismo z 23. 02.1920 r.; s. 20 - pismo z 18. $02.1920 \mathrm{r}$.

20 APP, SAP, sygn. 52, ss. 5-9 - okólnik L. 4; nr IIa 963/20; vid. Też Zbiór rozporzqdzeń, str. 200, poz. 2 (skrót). 
skiego Sądu Apelacyjnego o reagowanie na możliwe doniesienia skierowane przeciwko sędziom pokoju i przeprowadzanie dochodzeń w celu ustalenia, czy są oni godni sprawowanego urzędu.

Na początku lutego 1920 roku Prezes Sądu Apelacyjnego w Poznaniu zwrócił się do Prezesów sądów okręgowych z zapytaniem o realizację wytycznych wskazanych w okólniku z 9 stycznia 1920 roku. Skierowane do Sądu Apelacyjnego odpowiedzi pokazywały, że skomplikowane okazało się zwłaszcza przygotowanie konferencji sędziów pokoju w siedzibach sądów okręgowych, czego główną przyczyną były problemy komunikacyjne. Szczególnie szeroko do kwestii praktycznej realizacji postanowień rozporząadzeń z grudnia 1919 roku i styczniowego okólnika odnieśli się sędziowie poznańscy. Prezes Sądu Okręgowego w Poznaniu wydał w styczniu 1920 roku własny okólnik skierowany do sędziów pokoju w swoim okręgu. Dni posiedzeń sądów pokoju zostały odgórnie wyznaczone na cały nadchodzący rok. W piśmie zawarto także wskazówki dotyczące przeprowadzania posiedzeń, postępowania $\mathrm{z}$ lawnikami oraz wypełniania sprawozdań z działalności ${ }^{21}$. Okólnikom towarzyszyło pismo do naczelników sądów powiatowych, w którym poruczono bieżącą kontrolę nad działaniami sędziów pokoju ${ }^{22}$. Podkreślić przy tym należy fakt skomplikowania ówczesnej sytuacji w poszczególnych sądach powiatowych, co spowodowane było pozostawaniem w nich części niemieckich sędziów i urzędników sądowych aż do końca marca 1920 roku, zgodnie z postanowieniami wcześniejszych umów polsko-niemieckich z 1919 roku $^{23}$.

\section{Powstanie sądów pokoju w poszczególnych obwodach sądów okręgowych}

Najwięcej sądów powiatowych znalazło się w okręgu Sądu Okręgowego w Poznaniu. W obszarze linii demarkacyjnej były to sądy w: Poznaniu, Czarnkowie, Grodzisku, Nowym Tomyślu, Obornikach, Pniewach, Pobiedziskach, Rogoźnie, Śremie, Środzie, Szamotułach i Wronkach, zaś poza tym obszarem - w Chodzieży, Międzychodzie, Wieleniu i Zbąszyniu. Największą liczbę sędziów pokoju powołać miano zgodnie z planem dla Sądu Powiatowego w Poznaniu. Jego Prezes słał obszerne raporty do poznańskiego Sądu Apelacyjnego. Już 9 stycznia 1920 roku zawiadamiał o objęciu urzędu przez 5 sędziów pokoju w poprzednich dniach ${ }^{24}$. Kolejni dwaj sędziowie rozpoczęli pracę w następnych tygodniach. Z pisma z 23 lutego 1920 roku wynikało, że wszyscy ci sędziowie - poza jednym (w podeszłym wieku i chorym) - regularnie uczestniczyli w rozprawach, które

21 APP, SAP, sygn. 53, s. 21-25 - odpis okólnika Prezesa SO w Poznaniu z 22.01.1920 r. (L.I.119/270).

22 APP, SAP, sygn. 53, s. 31 - pismo Prezesa SO w Poznaniu z 22.01.1920 r. (L.I.190/270).

23 Zbiór rozporzqdzeń..., s. 9-11,17-18; A. Gulczyński, op. cit, s. 115-120.

24 APP, SAP, sygn. 53, s. 2 - pismo Prezesa SP w Poznaniu z 9. 01.1920 r. 
odbywały się raz w tygodniu i zostały już rozpisane na cały rok $^{25}$. Raporty z pozostałych sądów w okręgu Sądu Okręgowego w Poznaniu, położonych w obrębie linii demarkacyjnej, także wskazywały, iż sędziowie pokoju rozpoczęli swą działalność w miesiącu styczniu lub lutym ${ }^{26}$. Większe komplikacje pojawiły się w 4 sądach objętych przez polskie władze w późniejszym czasie. Sąd pokoju przy Sądzie Powiatowym w Międzychodzie odbył swe pierwsze posiedzenie dopiero 26 kwietnia 1920 roku $^{27}$. Pierwsze rozprawy przed sądem pokoju w Wieleniu wyznaczono na 27 maja 1920 roku, choć do lipca 1920 roku tylko jeden z trzech wyznaczonych sędziów faktycznie rozpoczął orzekanie. W Sądzie Powiatowym w Zbąszyniu sędzia pokoju przewodniczył przed 1 lipca 1920 roku jednemu posiedzeniu ${ }^{28}$. Najpóźniej działalność rozpoczął sąd pokoju przy Sądzie Powiatowym w Chodzieży. Z powodu niepodjęcia obowiązków przez pierwotnie wyznaczonych sędziów, w pracy sądu nastąpiło kilkumiesięczne opóźnienie i w efekcie pierwsza rozprawa przed sędzią pokoju dla spraw karnych w Chodzieży odbyła się dopiero 28 lipca $1920 \mathrm{roku}^{29}$.

Zgodnie z rozporządzeniem nr 182 Sądowi Okręgowemu w Bydgoszczy podlegać miały położone w obszarze linii demarkacyjnej sądy powiatowe w Inowrocławiu, Kcyni, Łabiszynie, Strzelnie, Szubinie i Żninie oraz położone poza tym obszarem sądy powiatowe w Bydgoszczy, Koronowie, Margoninie, Nakle, Łobżenicy i Wyrzysku. Z racji, iż Sąd Okręgowy w Bydgoszczy znajdował się poza linią demarkacyjną, podlegające mu formalnie wymienione sądy położone po polskiej stronie miały do czasu przejęcia Sądu Okręgowego przez polski wymiar sprawiedliwości podlegać pod kątem nadzoru służbowego Prezesowi Sądu Okręgowego w Gnieźnie. W największym z sądów powiatowych w tym okręgu - Sądzie Powiatowym w Bydgoszczy - sędziów pokoju mianowano dekretami z 12 i 22 lutego 1920 roku, choć nie wszyscy kandydaci przyjęli ostatecznie urząd $^{30}$. W Inowrocławiu pierwsze posiedzenia sądu pokoju odbyły się 28 lutego 1920 roku, w Kcyni sędzia pokoju stawił się w sądzie z nominacją już 9 stycznia 1920 roku, w tych samych dniach sędziowie zameldowali się w sądzie w Żninie ${ }^{31}$. W Koronowie

25 APP, SAP, sygn.53, s. 11-14 - pismo Prezesa SP w Poznaniu z 23. 02. 1920 r.

26 Np. APP, SAP, sygn. 347, k. 4 - SP Czarnków, pierwsza rozprawa 25. 02.1920 r.; sygn. 428, k. 4 - SP Pniewy, pierwsza rozprawa 19. $02.1920 \mathrm{r}$.

27 APP, SAP, sygn. 397, k. 8 - wykaz czynności sądu pokoju przy SP w Międzychodzie z 1. 07. $1920 \mathrm{r}$.

28 APP, SAP, sygn. 464, k. 20 - pismo Naczelnika SP w Wieleniu z 26.07 .1920 r.; sygn. 478, k. 5 - pismo Naczelnika SP w Zbąszyniu z 17. 08. $1920 \mathrm{r}$.

29 APP, SAP, sygn. 344, k. 5-5v - pismo Naczelnika SP w Chodzieży z 27. 07. 1920 r.

30 APP, SAP, sygn. 481, k. 1-2 - pisma z 12. 02.1920 r. i 22. 02.1920 r.; k. 3 - pismo z 5. 03.1920 r.; k. 6 - pismo Departamentu Sprawiedliwości z 29.03.1920 r. z przyjęciem rezygnacji trzech sędziów pokoju.

31 APP, SAP, sygn. 494, k. 1 - pismo Naczelnika SP w Inowrocławiu z 18. 02.1920 r.; sygn. 497, k. 2 - pismo Naczelnika SP w Kcyni z 9. 01.1920 r.; sygn. 527, k. 2 - pismo Naczelnika SP w Żninie z 16. 01.1920 r. 
sędzia pokoju Górzyński został mianowany w dniu 18 lutego 1920 roku, ale pierwsze posiedzenie sądu odbyło się dopiero 14 kwietnia, niemal tydzień później niż w Sądzie Powiatowym w Łabiszynie ${ }^{32}$. Natomiast sędziowie pokoju w Łobżenicy, Nakle i Wyrzysku rozpoczęli orzekanie dopiero w maju $1920 \mathrm{roku}^{33}$. Ze Strzelna pierwszy raport o wyznaczeniu sędziów pokoju nosił datę już 20 stycznia 1920 roku, jednakże w następnych miesiącach sąd borykał się z problemami kadrowymi ${ }^{34}$. Pod koniec marca 1920 roku odbyło się pierwsze posiedzenie sądu pokoju w Szubinie ${ }^{35}$.

Zgodnie z Rozporządzeniem nr 182 obwód Sądu Okręgowego w Gnieźnie obejmował sądy powiatowe w Gnieźnie, Mogilnie, Trzemesznie, Wągrowcu, Witkowie i Wrześni. 14 lutego 1920 roku Prezes Sądu Okręgowego w Gnieźnie Antoni Karpiński poinformował Departament Sprawiedliwości Ministerstwa o rozpoczęciu działalności przez wszystkie sądy pokoju przy sądach powiatowych w obwodzie Sądu Okręgowego w Gnieźnie. Wyjątkiem pozostawał Sąd Powiatowy w Witkowie, w którym sędzia pokoju do spraw karnych miał rozpocząć orzekanie w ciągu najbliższego tygodnia. Prezes Karpiński nie miał zastrzeżeń co do pracy sędziów niezawodowych, których pracę obserwował w Sądzie Powiatowym w Gnieźnie. Podkreślał, że rozprawy prowadzili „Z powagą i umiejętnością”36. Zachowane w aktach raporty z działalności sądów pokoju podlegających Sądowi Okręgowemu w Gnieźnie wskazują, iż sądy rozpoczęły swą działalność bez większych problemów ${ }^{37}$.

Raporty w sprawie działania sądów pokoju poczęły spływać również z obwodu Sądu Okręgowego w Lesznie, przejętego przez władze polskie 19 stycznia 1920 roku ${ }^{38}$. Oprócz położonych poza linią demarkacyjną sądów powiatowych w Lesznie, Bojanowie i Rawiczu (tych dwóch ostatnich przejętych 23 stycznia 1920 roku) Sądowi Okręgowemu podlegały sądy powiatowe w Gostyniu, Jutrosinie, Kościanie, Śmiglu i Wolsztynie ${ }^{39}$. W piśmie datowanym na 7 lutego 1920 roku Prezes Sądu Okręgowego w Lesznie Adam Ruszczyński donosił, że 4 i 5 lutego 1920 roku odbyły się pierwsze posiedzenia sądu

32 APP, SAP, sygn. 500, k. 3 - pismo Naczelnika SP w Koronowie z 26. 06.1920 r.; sygn. 503, k. 23 - pismo Prezesa SO w Bydgoszczy z 23. 06.1920 r.

33 APP, SAP, sygn. 506, k. 2 - pismo Prezesa SO w Bydgoszczy z 24. 06. 1920 r. (Łobżenica - 12. 05.1920 r.); sygn. 512, k. 2 - pismo Naczelnika SP w Nakle z 3. 08. 1920 r.; sygn. 524, k. 8-8v pismo Naczelnika SP w Wyrzysku z 7. 07.1920 r.

34 APP, SAP, sygn. 515, k. 1-8.

35 APP, SAP, sygn. 518, k. 1 - pismo Naczelnika SP w Szubinie z 20. 03.1920 r.

36 APP, SAP, sygn. 53, k. 8 - pismo Prezesa SO w Gnieźnie z 14. 02.1920 r.

37 Cf. przedstawienie historii sądu pokoju przy Sądzie Powiatowym we Wrześni - Sz. Paciorkowski, Poczatki polskiego Saqu Powiatowego we Wrześni w II RP, [w:] „Museion Wrzesiński” 2013, s. 43-46.

38 Zbiór rozporządzeń..., s. 194-195 (lista sądów przejętych przez władze polskie, wraz z datami przejęcia).

39 Przykładowy raport z działalności sądu pokoju przy SP w Gostyniu: APP, SAP, sygn. 356, k. 1-7. 
pokoju w Gostyniu i Śmiglu, a tydzień wcześniej w Jutrosinie i Kościanie. Prezes Ruszczyński, osobiście obecny na posiedzeniach sądu w Gostyniu i Śmiglu, podkreślał, iż wprawdzie orzekający sędziowie pokoju „nie byli jeszcze dość biegli w załatwianiu formalności”, ale za to „byli bardzo dobrze przygotowaniu, znali doskonale akta i trafnie wyrokowali” ${ }^{40}$. Dzień wcześniej (6 lutego 1920 roku) Prezes Ruszczyński podał, iż sądy pokoju w Bojanowie, Lesznie i Rawiczu wkrótce rozpoczną urzędowanie ${ }^{41}$. Stwierdzenie to okazało się nietrafne w odniesieniu do Rawicza. Problemy ze znalezieniem sędziów pokoju i porozumieniem w kwestii kompetencji doprowadziły do tego, iż pierwsze posiedzenie sądu odbyło się dopiero 11 maja 1920 roku $^{42}$.

W okręgu Sądu Okręgowego w Ostrowie jedynie sąd powiatowy w Kępnie - jako leżący poza obszarem linii demarkacyjnej - przeszedł pod polski zarząd później. Tam też pierwsze posiedzenia sądu pokoju odbyły się jako ostatnie, bo dopiero 24 kwietnia 1920 roku $^{43}$. Pozostałe sądy powiatowe - w Jarocinie, Koźminie, Krotoszynie, Odolanowie, Ostrowie, Ostrzeszowie i Pleszewie - objęte zostały przez polską administrację z dniem 1 stycznia 1920 roku. O początkach działalności sądów pokoju raportował Prezes ostrowskiego Sądu Okręgowego - Władysław Lehmann i naczelnicy sądów powiatowych. Sędziowie pokoju przy Sądzie Powiatowym w Jarocinie rozpoczęli orzekanie 10 marca 1920 roku, a w Koźminie do połowy czerwca 1920 roku odbyło się 12 posiedzeń sądu pokoju ${ }^{44}$. W Ostrzeszowie trzej sędziowie pokoju orzekali od 6 marca 1920 roku, odbywając do 26 czerwca 1920 roku 16 posiedzeń ${ }^{45}$. W zachowanych aktach brak wzmianek o tym, by sędziowie pokoju w Krotoszynie, Odolanowie, Ostrowie czy Pleszewie rozpoczęli orzekanie ze znaczącym opóźnieniem.

\section{Wybrane problemy działania sądów pokoju w pierwszych miesiącach 1920 roku}

Już od pierwszych miesięcy działania sądów pokoju występowały problemy z ich obsadą. Niektórzy wyznaczeni sędziowie odmawiali podjęcia obowiązków, inni rezygnowali po krótkim czasie ${ }^{46}$. Z załączonych do akt rezygnacji - kierowanych do Departamentu Sprawiedliwości zarówno w pierwszym kwartale 1920 roku, jak i w późniejszych la-

40 APP, SAP, sygn. 51, k. 12-13 - pismo Prezesa SO w Lesznie z 7. 02.1920 r.

41 APP, SAP, sygn. 53, k. 9 - pismo z 15.02.1920 r.

42 APP, SAP, sygn. 482, k. 7 - pismo Prezesa SO w Lesznie z 15. 06. 1920 r.

43 APP, SAP, sygn. 370, k. 14 - pismo Naczelnika SP w Kępnie z 16. 06.1920 r.

44 APP, SAP, sygn. 364, k. 3 - pismo Prezesa SO w Ostrowie z 20. 04.1920 r.; sygn. 378, k. 3-3v pismo Naczelnika SP w Koźminie z 23. 06. 1920 r.

45 APP, SAP, sygn. 411, k. 2 - pismo Naczelnika SP w Ostrzeszowie z 26. $06.1920 \mathrm{r}$.

46 Vid.np. APP, SAP, sygn. 350, k. 10 (Gniezno); sygn. 370, k. 4 (Kępno);sygn. 403, k. 11 (Oborniki); sygn. 494, k. 3-4 (Inowrocław); sygn. 521, k. 6 (Trzemeszno);sygn. 464, k. 9 (Wieleń); sygn. 487, k. 1-3 (Rawicz). 
tach - wynika, iż najczęstszymi przyczynami odmowy sprawowania urzędu sędziego lub wniosków o zwolnienie ze sprawowanej już funkcji były: niemożność pogodzenia obowiązków zawodowych ze służbą społeczną, zbyt duże obciążenie finansowe związane ze sprawowaniem funkcji, wreszcie zmiana miejsca zamieszkania. Bywały także mniej typowe przypadki, spośród których warto wspomnieć przykład Jana Drzewieckiego, tłumaczącego swą odmowę sprawowania urzędu sędziego pokoju przy Sądzie Powiatowym w Chodzieży faktem, iż jako robotnika nie stać go było na zakup „tak przyzwoitego ubioru", by mógł występować w sądzie ${ }^{47}$. Osobną kwestią była nieposzlakowana opinia, jaką winni byli się cieszyć sędziowie pokoju, orzekający przecież w sprawach swej lokalnej społeczności. Już na początku działalności sądów pokoju zdarzały się sytuacje wywołujące kontrowersje: w Sądzie Powiatowym w Pobiedziskach okazało się, że przeciwko jednemu z sędziów pokoju prowadzone jest postępowanie egzekucyjne, zaś sam sędzia nie zamierzał podporządkować się zarządzeniom komornika. Szybka reakcja przełożonych doprowadziła do zawieszenia sędziego, który następnie sam złożył rezygnację z urzędu w kwietniu 1920 roku $^{48}$.

Kolejnym naglącym problemem, z którym musiały uporać się nowe władze polskie, była kwestia wynagrodzenia sędziów pokoju. Zgodnie z art. 11 rozporządzenia nr 186 pełnili oni funkcję honorowo, otrzymując jedynie zwrot kosztów w wysokości od 2000 do 4000 marek rocznie, w zależności od zakresu ich działalności. Natomiast wynagrodzenie zastępców sędziów miało być uzależnione od miejsca zamieszkania: zastępcy mieszkający w siedzibie sądu pokoju mieli otrzymywać 40 marek za każde posiedzenie sądowe, natomiast zastępcy mieszkający poza siedzibą sądu - 60 marek.

Jak wskazano powyżej, rozróżnienie na stałych sędziów pokoju i ich zastępców napotkało na problemy praktyczne. Zapewne w związku z tymi okolicznościami w piśmie Departamentu Sprawiedliwości MBDP z 23 lutego 1920 roku odniesiono się tylko dozwrotu kosztów w kwocie od 2000 do 4000 marek rocznie, przesyłając Prezesowi Sądu Apelacyjnego polecenie ustalenia propozycji wysokości odszkodowania dla poszczególnych sędziów w terminie 2 tygodni na podstawie załączonego formularza ${ }^{49}$. Formularz ten zawierał dane o zawodach sędziów pokoju, przypuszczalnej rocznej liczbie spraw, posiedzeń i uśrednionych godzin codziennego zatrudnienia, jak również informacje o odległości miejsca zamieszkania od miejsca urzędowania i proponowanej wysokości zwrotu kosztów. Wspomniane pismo wpłynęło do Sądu Apelacyjnego 4 marca 1920

47 APP, SAP, sygn. 344, k. 12 - odpis pisma Jana Drzewieckiego z 21.07.1920 r. Jego rezygnacja została jednak ostatecznie przyjęta dopiero w styczniu 1921 r., choć w rzeczywistości nigdy nie podjął urzędowania - vid. APP, SAP, sygn. 344, k. 15 i k. 16.

48 APP, SAP, sygn. 431, k. 3-13. Zapewne właśnie konieczność sprawdzenia przez władze sądowe kwalifikacji sędziów pokoju doprowadziła do wydania polecenia obowiązkowego sporządzenia przez wszystkich sędziów własnoręcznych życiorysów, które nadsyłano do Sądu Apelacyjnego w lecie $1920 \mathrm{r}$.

49 APP, SAP, sygn. 53, s. 34 - pismo Departamentu Sprawiedliwości z 23. 02.1920 r. 
roku. W następnych tygodniach do Poznania spływały formularze wypełnione przez Prezesów sądów okręgowych, co zajęło jednak więcej czasu, niż zakładał to Departament Sprawiedliwości. W marcu 1920 roku nadeszły raporty z Sądu Okręgowego w Bydgoszczy i Sądu Okręgowego w Poznaniu. Prezes Sądu Okręgowego w Gnieźnie przesłał sprawozdanie o proponowanej wysokości wynagrodzenia w dwóch turach - 19 kwietnia i 18 maja $1920 \mathrm{roku}^{50}$. Prezes ostrowskiego Sądu Okręgowego przesłał formularz dopiero 5 czerwca 1920 roku, zaznaczając jednak, że jest jeszcze zbyt wcześnie na ustalenie ostatecznej wysokości odszkodowania ${ }^{51}$. Prezes Sądu Okręgowego w Lesznie w ogóle nie przedstawił projektu, wskazując, że ustalenie proponowanej kwoty nie będzie możliwe, dopóki nie zyska „dostatecznego poglądu na zakres działalności poszczególnych sędziów”, co w jego opinii mogło nastąpić dopiero w październiku lub listopadzie ${ }^{52}$. Trudny do rozwiązania problem ustalenia odpowiedniej wysokości zwrotu kosztów dla sędziów pokoju doprowadził wkrótce do wydania nowych przepisów w tej materii ${ }^{53}$.

Pierwsze miesiące urzędowania wiązały się również z wątpliwościami dotyczącymi kompetencji i jakości orzecznictwa sędziów pokoju. $Z$ jednej strony, sędziowie ci otrzymali szeroki zakres obowiązków: na mocy art. 4 rozporządzenia nr 186 przysługiwało im prawo wydawania mandatów karnych, a zgodnie $z$ art. 5 tegoż rozporządzenia zobowiązani byli do przygotowania rozprawy głównej. $Z$ drugiej strony, nacisk położony został na wsparcie dawane niezawodowym sędziom przez naczelników sądów, przejawiające się choćby w obowiązku wykonania wyroków w sprawach podlegających sądom pokoju czy udzielania wyjaśnień w kwestiach prawnych wchodzących w zakres właściwości sądów pokoju (art. 6 i art. 7 rozporządzenia nr 186). Do problemów stosowania przepisów ustawowych do działania sądów pokoju odniósł się między innymi wydany 18 lutego 1920 roku okólnik Departamentu Sprawiedliwości ${ }^{54}$. Zgodnie z postanowieniami kolejnego okólnika z dnia 2 marca 1920 roku Prezes Sądu Apelacyjnego w Poznaniu zobowiązany został do zwrócenia się do Prezesów sądów okręgowych o pouczenie sędziów pokoju, by z pytaniami o wyjaśnienie zakresu działania i interpretację przepisów zwracali się do nich, a nie bezpośrednio do Departamentu Sprawiedliwości, gdyż „obecnie zdarzają się coraz częściej wypadki, że w sprawach zupełnie błahych sędziowie pokoju wprost do Departamentu skierowują zapytania, na które odpowiedź mogliby otrzymać od Prezesa Sądu Okręgowego" 55 .

50 APP, SAP, sygn. 53, s. 46 - pismo Prezesa SO w Gnieźnie z 18.05.1920 r.

51 APP, SAP, sygn. 53, s. 52 - pismo Prezesa SO w Ostrowie z 5. 06. 1920 r.

52 APP, SAP, sygn. 53, s. 51 - pismo Prezesa SO w Lesznie z 17.03.1920 r.

53 Okólnik 1.126 z 29. 07. 1920 r. w przedmiocie wynagrodzenia sędziów pokoju; rozporządzenie z 25. 01. $1921 \mathrm{r}$. w sprawie zwrotu kosztów i odszkodowania za stratę czasu dla sędziów pokoju w byłej dzielnicy pruskiej (DzUMbDP, nr 5 z 1921 r., poz. 25, s. 75).

54 APP, SAP, sygn. 52, s. 10, s. 17 - Okólnik Departamentu Sprawiedliwości L. 11 z 18. 02.1920 r.

55 APP, SAP, sygn. 52, s. 18 - Okólnik Departamentu Sprawiedliwości L. 19 z 2. 03. 1920 r. (4.IIa.6615/20). 
Wgląd w praktykę orzeczniczą sądów pokoju w pierwszych miesiącach ich działania dają zachowane w części akt Sądu Apelacyjnego sprawozdania z lustracji przeprowadzonych przez instruktora dla sędziów pokoju Jana Cegielskiego, który w drugiej połowie kwietnia i maju 1920 roku zmierzył zachodnią i południową Wielkopolskę ${ }^{56}$. W pierwszej części tych raportów przedstawiano stan osobowy sądów pokoju przy odwiedzonym sądzie powiatowym, jak również częstotliwość posiedzeń sądu i sposób ich wyznaczania. W dalszej kolejności w formie danych liczbowych analizowano tok czynności w sądzie pokoju, w tym liczbę spraw, które wpłynęły do sądu w pierwszych miesiącach jego działalności i które zostały już załatwione, a także liczbę dotychczasowych posiedzeń sądu. Instruktor omawiał również pokrótce jakość protokołów rozpraw. Sprawozdania zawierały ponadto omówienie posiedzeń, które wizytował instruktor i jego spostrzeżenia. Końcowe fragmenty odnosiły się do zwięzłej oceny postawy i jakości pracy sędziów pokoju, a także do ewentualnych uwag i wniosków na przyszłość. Podkreślić należy, iż w żadnym z zachowanych sprawozdań praca sędziów pokoju nie została poddana wyraźnej krytyce, przy czym zwracano uwagę na zbyt krótki czas dotychczasowego funkcjonowania sądów, by móc dokonać całościowej oceny. Do pracy części sędziów pojawiły się natomiast pewne zastrzeżenia, związane choćby ze zbyt słabą znajomością przepisów, czy problemami w przygotowaniu uzasadnień orzeczeń ${ }^{57}$. Oprócz kontroli przeprowadzonej przez instruktora Cegielskiego Sąd Apelacyjny w Poznaniu kierował w pierwszej połowie roku 1920 roku zapytania do poszczególnych Prezesów sądów okręgowych w kwestii bieżącej działalności sądów pokoju ${ }^{58}$.

Końcowym akcentem w działalności sądów pokoju w pierwszym półroczu 1920 roku stała się kwestia rozszerzenia zakresu kompetencji sędziów pokoju o orzekanie również w drobnych sprawach cywilnych. Już 24 kwietnia 1920 roku odbyła się w biurze Szefa Departamentu Sprawiedliwości MBDP Poznaniu konferencja poświęcona tej kwestii, na którą zaproszono po „3 najwybitniejszych sędziów pokoju z każdego Sądu Okręgowego" ${ }^{59}$. Przez następne dwa miesiące trwały prace i konsultacje nad projektem

56 Zachowały się protokoły z wizytacji przeprowadzonych tylko w okręgu SO w Poznaniu i SO w Lesznie, być może zatem w pozostałych okręgach wizytacje się nie odbyły. APP, SAP, sygn. 341, k. 8-9 (Bojanowo, 23.04.1920 r.); sygn. 356, k. 8-9v (Gostyń, 20.-21. 04. 1920 r.); sygn. 360, k. 6-7 (Grodzisk Wlkp.); sygn. 367, k. 3-4 (Jutrosin, 26-27. 04. 1920 r.); sygn. 375, k. 3-4 (Kościan, 24. i 30 .04. 1920 r.); sygn. 390, k. 4-5 (Leszno, 19 i 22. 04.1920 r.); sygn. 400, k. 3-4 (Nowy Tomyśl, 19. 05. 1920 r.); sygn. 446, k. 5-6 (Śmigiel, 29. 04. 1920 r.); sygn. 449, k. 3-4 (Śrem, 27. 04. 1920 r.); sygn. 452, k. 3-4 (Środa, 11-12. 05.1920 r.); sygn. 470, k. 3-4 (Wolsztyn, 6-7. 05. 1920) r.; sygn. 487, k. 8-8v (Rawicz, 20. 04. 1920 r. - sąd jeszcze nie działał).

57 Zob. APP, SAP, sygn. 341, k. 9;

58 Np. APP, SAP, sygn. 467, k. 3 - pismo Naczelnika SP w Witkowie z 30.06 .1920 r.; sygn. 509, k. 5 - pismo Naczelnika SP w Mogilnie z 28. 06. 1920 r.; sygn. 518, k. 2 - pismo Naczelnika SP w Szubinie z 26. 06. 1920 r.; sygn. 527, k. 6 - pismo Naczelnika SP w Żninie z 21. 07.1920 r.;

59 APP, SAP, sygn. 53, s. 84 - pismo Departamentu Sprawiedliwości z 12. 04.1920 r. (L. 4. IIa.10424/20). 
rozporządzenia, sondowano potencjalnych kandydatów na sędziów pokoju dla spraw cywilnych ${ }^{60}$. Ukoronowaniem tych starań było rozporządzenie Ministra byłej Dzielnicy Pruskiej z dnia 23 czerwca 1920 roku $^{61}$, w którym znowelizowano niemiecką ustawę o ustroju sądownictwa i dodano do niej przepis $\$ 22$ a o następującym brzmieniu:

Szef Departamentu Sprawiedliwości Ministerstwa b. dzielnicy pruskiej może na przeciąg czasu, jaki uzna za odpowiedni, w Sądach Powiatowych poruczyć sędziom pokoju za ich zgodą orzecznictwo w cywilnych sprawach w zakresie właściwości Sądów Powiatowych. Sędziemu pokoju, który ma wykonywać orzecznictwo w cywilnych sprawach, z reguły nie należy powierzać wykonywania orzecznictwa karnego. Szef Departamentu Sprawiedliwości Ministerstwa b. dzielnicy pruskiej ustali zasady, które należy przestrzegać przy przydzielaniu sędziom pokoju spraw cywilnych. Uchybienie tym zasadom nie pociąga za sobą ujemnych skutków prawnych.

Termin wejścia w życie rozporządzenia ustalono dopiero na 16 września 1920 roku. Jego uzupełnieniem było zarządzenie wykonawcze, zawierające instrukcje dla sędziów pokoju mających orzekać $\mathrm{w}$ sprawach cywilnych, a także okólniki ${ }^{62}$. W następnych miesiącach trwało ustalanie listy sędziów pokoju dla spraw cywilnych, ich szkolenie i wydawanie dalszych zarządzeń ${ }^{63}$.

\section{Podsumowanie}

Lato 1920 roku stanowiło ważną cezurę w początkowej działalności sędziów pokoju. Zmianą najważniejszą było zasygnalizowane już powyżej mianowanie nowych sędziów orzekających w drobnych sprawach cywilnych. Po okresie przejmowania wymiaru sprawiedliwości przez władze polskie stan osobowy sądów zaczynał się stabilizować. Sędziowie pokoju, którzy objęli swój urząd, wdrażali się w rutynę orzeczniczą.

Podsumowując, podkreślić należy, iż z jednej strony, pierwsze miesiące działalności sądów pokoju pozwoliły osiągnąć wiele sukcesów. Ich sieć udało się utworzyć przy

$60 \mathrm{~W}$ przedmiocie powierzenia sędziom pokoju orzecznictwa w sprawach cywilnych wydano również okólnik nr $67 \mathrm{z}$ dnia 31. 05.1920 r. (Nr dz. 4.II.a.14952/20).

61 Rozporządzenie z 23. 06. 1920 r. o dalszej zmianie niektórych przepisów niemieckiej ustawy o ustroju sądownictwa i o uproszczeniu postępowania w cywilnych sprawach spornych; DzUMbDP, Nr 34 z 1920, poz. 304.

62 Zarządzenie wykonawcze do rozporządzenia z dnia 23 czerwca 1920 r., DzUMbDP z 1920, nr 34, poz. 307.

$63 \mathrm{~V}$. okólnik 1.106 z 6.07.1920 r. w przedmiocie zmian przepisów niemieckiej ustawy o ustroju sądownictwa oraz adwokatury w b. dzielnicy pruskiej (L. dz. 4.II.a.18351/20; cyt. za: Zbiór rozporzadzeń..., s. 246-248); APP, SAP, sygn. 54, s. 1-6 - pismo Prezesa SA w Poznaniu z 11.08.1920 r. ws. kandydatów na sędziów pokoju ds. cywilnych w poszczególnych sądach powiatowych 
wszystkich sądach powiatowych podległych Sądowi Apelacyjnemu w Poznaniu, a sędziowie - w większości niemający przecież wcześniej związków z wymiarem sprawiedliwości - rozpoczęli urzędowanie. Co więcej, protokoły wizytacji wskazują, że do jakości ich orzecznictwa nie było na razie większych zastrzeżeń.

$Z$ drugiej strony, już w tych właśnie pierwszych miesiącach działalności sądów pokoju dały o sobie znać problemy, które miały nękać tę instytucję w następnych latach. W artykule omówiono kwestie rezygnacji sędziów pokoju z zajmowanych przez nich stanowisk, odmowy podejmowania tej służby, a także niewystarczających wynagrodzeń, przyznawanych sędziom, którzy musieli godzić swoje obowiązki zawodowe $\mathrm{z}$ obowiązkami sądowymi. Niniejszy szkic miał na celu zasygnalizowanie tych komplikacji i otwarcie pola do dalszych badań nad działalnością niezawodowych sędziów w pierwszych latach II RP.

\section{SUMMARY}

The first months of the activities of the courts of peace in the Court of Appeal in the Poznan circuit in the light of the court files from the Court of Appeal in Poznan

The aim of the paper is to present the activities of the courts of peace in the Court of Appeal in the Poznan circuit in the Polish Second Republic in the first months of their existence in 1920. The courts of peace were established in the former Prussian partition by the Polish authorities because of the shortage of Polish legal professionals. Justices of the peace were appointed from the local citizenry and most of them had no formal legal education. The article, which is primarily based on the study of court files from the Court of Appeal in Poznan, deals with selected problems concerning the implementation of the courts of peace, like issues connected with the appointment of new justices and the financial compensation for their activities at court.

Keywords: courts of peace, justices of peace, Polish Second Republic, Court of Appeal in Poznan 